Journal of Sports Medicine and Allied Health Sciences: Official Journal of the Ohio Athletic Trainers Association

March 2020

\title{
Effective Treatment Of An Apparent Lateral Ankle Sprain Using A Regional Interdependent Approach With Positional Release Therapy And Mulligan Concept
}

Joshua K. Underwood

University of Nebraska, Kearney, VTraptor@gmail.com

Follow this and additional works at: https://scholarworks.bgsu.edu/jsmahs

Part of the Alternative and Complementary Medicine Commons, Exercise Science Commons, Other Kinesiology Commons, Rehabilitation and Therapy Commons, Sports Medicine Commons, and the Sports Sciences Commons

How does access to this work benefit you? Let us know!

\section{Recommended Citation}

Underwood, Joshua K. (2020) "Effective Treatment Of An Apparent Lateral Ankle Sprain Using A Regional Interdependent Approach With Positional Release Therapy And Mulligan Concept," Journal of Sports Medicine and Allied Health Sciences: Official Journal of the Ohio Athletic Trainers Association: Vol. 5: Iss. 3 , Article 4.

DOI: https://doi.org/10.25035/jsmahs.05.03.04

Available at: https://scholarworks.bgsu.edu/jsmahs/vol5/iss3/4

This Article is brought to you for free and open access by the Journals at ScholarWorks@BGSU. It has been accepted for inclusion in Journal of Sports Medicine and Allied Health Sciences: Official Journal of the Ohio Athletic Trainers Association by an authorized editor of ScholarWorks@BGSU. 


\title{
Effective Treatment of an Apparent Lateral Ankle Sprain Using a Regional Interdependent Approach with Positional Release Therapy and Mulligan Concept
}

\author{
Joshua K. Underwood, DAT, LAT, PRT-c, CPN \\ University of Nebraska-Kearney
}

Objective: Present a pair of clinical cases demonstrating the utilization of regional interdependent (RI) evaluation and treatment in an apparent lateral ankle sprain. The utilization of both Positional Release Therapy (PRT) and Mulligan Concept (MC) on secondary school athletes with an apparent acute lateral ankle sprain are presented. Background: Lateral ankle sprains are a common injury in athletics. While the MC has been shown to be effective manual therapy in ankle sprains, if the treatment is not pain-free it is considered not warranted. The concept of RI attempts to connect apparently unconnected dysfunctions within the body which collectively contribute to a patient's complaint of pain or pathology. Treatment: The patients were successfully treated in one treatment session using a RI approach after failing to obtain a PILL effect while using MC during their initial evaluation. The patients experienced minimal clinically-important changes on a variety of patient related outcomes. Uniqueness: To the author's knowledge, there are currently no published articles reporting the use of RI methods of evaluation and treatment in apparent lateral ankle sprain pathologies. Conclusion: The utilization of an RI approach as an evaluation and treatment technique in patients suspected of having acute lateral ankle sprains. Keywords: Ankle sprains, Regional interdependence, Positional release therapy

\section{INTRODUCTION}

Approximately 28,000 ankle pathologies occur across the country everyday. ${ }^{1-3}$ Lateral ankle sprains (LAS) result in patient missed days of competition, lead to difficulties with activities of daily living (ADLs), and increase demands on healthcare providers. ${ }^{1-5}$ While LAS prevention, diagnosis and treatment continue to be studied, no one specific treatment method of patients diagnosed with LAS has been recognized as the gold standard.1,3,6-16

Regional interdependence (RI) is a concept which attempts to connect apparently unconnected dysfunctions within the body which collectively contribute to a patient's complaint of pain or pathology. ${ }^{17,18}$ Within this concept, somatovisceral, musculoskeletal, biopsychosocial, and neurophysiological all play an equal part in the health or recovery of a patient.17,18 It is theorized that poor outcomes from current protocols could be directly correlated to not incorporating a more holistic approach within patient's rehabilitation plans. ${ }^{17,18}$ Protocols not addressing all four aspects of RI may not be successful in breaking the allostatic cycle associated with injury. ${ }^{17,18}$ Due to the relative new nature of the term RI, there are very few articles utilizing RI as a direct method of treatment; however, more articles are coming out slowly as RI concept is being investigated in such conditions as ankle sprains, back pain, or knee pathologies. ${ }^{17,18}$

Positional Release Therapy is an indirect manual therapy technique in which the treating clinician identifies a position of comfort (POC) (e.g., decrease tension of effected tissue assessed by tender point (TP) palpation) which promotes the release of fascial contraction(s) (i.e., somatic dysfunction). ${ }^{19-23}$ Once the tissue is placed into a POC, there can be a low grade spasm contained in the tissue referred to as a fasciculation. ${ }^{19-23}$ The Fasiculatory Response Method can be utilized in determining the length of time a POC is sustained; however, the POC may need to be held from 20 seconds to 
several minutes. ${ }^{19,20}$ Once the fasciculation has ceased (e.g., sub grade spasms, heat, pins and needles) the clinician slowly brings the body part back to a neutral position and reassesses the TP.19,20 Positional Release Therapy studies have provided encouraging evidence as an effective therapeutic modality for a variety of pathologies. ${ }^{20-25}$

A form of joint mobilizations called the Mulligan Concept (MC) is a form of manual therapy in which the clinician applies a sustained passive accessory glide while the patient performs an active movement, also referred to as mobilizations with movement (MWM). One of the primary principles of MC is the PILL response in whether or not MWM are warrented. ${ }^{26}$ PILL is an acronym for Painfree, Immediate effect, and Long Lasting. ${ }^{26}$ If a PILL response is not present during an MWM, then the MC intervention is not indicated and the clinician should try alternative methods of therapy. 26

The purpose of this case report is to present the effectiveness of utilizing a RI approach in the treatment of an apparent LAS when a PILL response was not found initially and the patients complained of ipsilateral hip pain while performing dorsiflexion (DF) Theraband(C) exercises. Patient related outcomes were collected involving pain, function, and disability to evaluate the effectiveness of this novel RI approach.

\section{CASE REPORT}

Patient one was a 17-year-old male basketball player came into the athletic training clinic with a primary complaint of left lateral ankle pain after landing on a teammate's foot during a layup drill 30 minutes into practice. The patient stated the pain was a 4/10 on the numerical rating scale (NRS) while weight bearing (WB), 7/10 NRS for running, and 4/10 NRS with palpation over the anterior talofibular ligament (ATFL). The patient completed all outcome measures prior to treatment (Table 1). Patient one presented with slight laxity with anterior drawer test, tender to palpate over the ATFL, normal gait pattern, and lacking $17^{\circ}$ of dorsiflexion (DF) in his left ankle when compared bilaterally. Patient one was classified with a grade two lateral ankle sprain (Table 2). The primary researcher attempted to find a PILL response with the MC fibular glide; however, no PILL effect could be found. When patient one attempted to perform TB resisted DF with a blue band, the patient complained of lacking the ability to perform said movement and simultaneously stated they had ipsilateral anterolateral hip pain. After further evaluation, patient one had a TP at the Sartorius origin on the ipsilateral limb (Figure 1A).

Patient two came in about two months later with a very similar presentation. Patient two was a 16-year-old female lacrosse player who stepped into a divot on the field 25 hours earlier causing the right ankle to invert. The patient complained of pain with running, cutting, WB, and shooting.

After collecting outcome measures, the patient presented with only slight laxity with anterior drawer test, TP over the ATFL and Sartorius origin, lacked $15^{\circ}$ of DF, absent PILL effect with MC fibular glide, and pain with performing TB DF exercises (see Table 1). Patient two was similarly classified as sustaining a grade two lateral ankle sprain.

\section{OUTCOME MEASURES}

Pain was assessed using the NRS while the patients performed a weight-bearing SLS. The NRS is an 11-point Likert scale for patients to self-report pain and is intended for adults and children aged 10 years and older. ${ }^{27}$ A rating of 0 indicates no pain, a score of 1-3 indicates mild pain, a score of 4-6 indicates moderate pain, and a score of 7-10 indicates severe pain. ${ }^{27}$ A minimal clinically important difference (MCID), which is the smallest amount of change that is meaningful to the patient, for the NRS is any change greater than or equal to 2.0.27 


\begin{tabular}{|c|c|c|c|c|c|c|c|}
\hline \multirow[b]{2}{*}{ PRO } & \multicolumn{7}{|l|}{ Patient 1} \\
\hline & $\begin{array}{l}\text { Initial } \\
\text { Evaluation }\end{array}$ & $\begin{array}{l}\text { Post First } \\
\text { PRT } \\
\text { Treatment }\end{array}$ & $\begin{array}{l}\text { Post PRT \& MC } \\
\text { First Treatment }\end{array}$ & $\begin{array}{l}24 \quad \text { hour } \\
\text { Follow-up }\end{array}$ & $\begin{array}{l}1 \text { Week } \\
\text { Follow-up }\end{array}$ & $\begin{array}{l}2 \text { Week } \\
\text { Follow- } \\
\text { up }\end{array}$ & $\begin{array}{l}1 \text { Month } \\
\text { Follow-up }\end{array}$ \\
\hline DF AROM & $-5^{\circ}$ & $12^{\circ}$ & $12^{\circ}$ & $13^{\circ}$ & $11^{\circ}$ & $15^{\circ}$ & $15^{\circ}$ \\
\hline ATF NRS & 4 & $1^{\mathrm{a}}$ & 0 & 0 & 0 & .5 & 0 \\
\hline $\begin{array}{l}\text { Sartorius } \\
\text { NRS }\end{array}$ & 6 & $0^{\mathrm{a}}$ & 0 & 0 & 0 & 0 & 0 \\
\hline DF NRS & 5 & $0^{\mathrm{a}}$ & 0 & 0 & 0 & 0 & 0 \\
\hline SLS NRS & 4 & $.5^{\mathrm{a}}$ & 0 & .5 & 0 & 1 & 0 \\
\hline $\begin{array}{l}\text { Walking } \\
\text { NRS }\end{array}$ & 6 & $.5^{\mathrm{a}}$ & 0 & 0 & 0 & 0 & 0 \\
\hline $\begin{array}{l}\text { Running } \\
\text { NRS }\end{array}$ & 9 & $7^{a}$ & $1^{\mathrm{a}}$ & 0 & 0 & 0 & 0 \\
\hline DPA & 21 & $\sim$ & $\sim$ & $4^{\mathrm{a}}$ & 2 & 0 & 0 \\
\hline PFSF & 3.5 & $\sim$ & $\sim$ & $8.3^{\mathrm{a}}$ & 10 & 10 & 10 \\
\hline FAAM & 67 & $\sim$ & $\sim$ & $83^{\mathrm{a}}$ & $98^{\mathrm{a}}$ & 98 & 99 \\
\hline $\begin{array}{l}\text { FAAM } \\
\text { sport }\end{array}$ & 38 & $\sim$ & $\sim$ & $75^{a}$ & $100^{a}$ & 100 & 97 \\
\hline
\end{tabular}

\begin{tabular}{|c|c|c|c|c|c|c|c|}
\hline & Patient 2 & & & & & & \\
\hline PRO & $\begin{array}{l}\text { Initial } \\
\text { Evaluation }\end{array}$ & $\begin{array}{l}\text { Post First } \\
\text { PRT } \\
\text { Treatment }\end{array}$ & $\begin{array}{l}\text { Post PRT \& MC } \\
\text { First Treatment }\end{array}$ & $\begin{array}{l}24 \text { hour } \\
\text { Follow-up }\end{array}$ & $\begin{array}{l}1 \quad \text { Week } \\
\text { Follow-up }\end{array}$ & $\begin{array}{l}2 \text { Week } \\
\text { Follow- } \\
\text { up }\end{array}$ & $\begin{array}{l}1 \text { Month } \\
\text { Follow-up }\end{array}$ \\
\hline DF AROM & $4^{\circ}$ & $15^{\circ}$ & $17^{\circ}$ & $15^{\circ}$ & $16^{\circ}$ & $18^{\circ}$ & $18^{\circ}$ \\
\hline ATF NRS & 3 & $0^{\text {a }}$ & 0 & .5 & 0 & 0 & 0 \\
\hline $\begin{array}{l}\text { Sartorius } \\
\text { NRS }\end{array}$ & 5 & 0 a & 0 & 0 & 0 & 0 & 0 \\
\hline DF NRS & 4 & 0 a & 0 & 0 & 0 & .5 & 0 \\
\hline SLS NRS & 6 & $0^{\mathrm{a}}$ & 0 & 0 & 0 & 0 & 0 \\
\hline $\begin{array}{l}\text { Walking } \\
\text { NRS }\end{array}$ & 5 & $1^{a}$ & 0 & 0 & 0 & 0 & 0 \\
\hline $\begin{array}{l}\text { Running } \\
\text { NRS }\end{array}$ & 9.5 & $5^{\mathrm{a}}$ & $0^{\mathrm{a}}$ & .5 & 0 & 0 & 0 \\
\hline DPA & 12 & $\sim$ & $\sim$ & 3 & 0 & 0 & 0 \\
\hline PFSF & 5.7 & $\sim$ & $\sim$ & 9.3 & 9.7 & 10 & 10 \\
\hline FAAM & 71 & $\sim$ & $\sim$ & 86 & 93 & 100 & 100 \\
\hline $\begin{array}{l}\text { FAAM } \\
\text { sport }\end{array}$ & 59 & $\sim$ & $\sim$ & 88 & 94 & 100 & 97 \\
\hline
\end{tabular}

Table 1. Outcome Measures Through Treatment, Discharge, and Follow-ups

NRS = Numerical Rating Scale; DPA= Disablement in the Physically Active; PSFS= Patient Specific Functional Scale; FAAM= Foot and

Ankle Ability Measure; The use of " $\sim$ " indicates a score was not recorded at this point; The utilization of $-^{\circ}$ indicates the degree of movement measured in which the patient is lacking movement in regards to neutral.

a Denotes minimal clinically-importance difference from previous measurement

Numeric Rating Scale values were recorded during palpation (specifically ATF and Sartorius origin) (Figures 1A), performing DF, walking, running, and performing a SLS by standing on the involved ankle with no shoe or sock on while holding the contralateral hip/knee at $90^{\circ}$ flexion for 10 seconds. Numerical rating scale measurements were recorded during initial evaluations, postinterventions, 24 hours after treatment sessions, and at discharge. 


\begin{tabular}{|c|c|c|c|c|c|c|}
\hline $\begin{array}{l}\text { Sprain } \\
\text { Classification }\end{array}$ & $\begin{array}{l}\text { Anterior } \\
\text { Drawer }\end{array}$ & $\begin{array}{lr}\text { Figure } & 8 \\
\text { Measurement }\end{array}$ & $\begin{array}{ll}\text { Tender } & \text { to } \\
\text { Palpate } & \\
\end{array}$ & SLS & NWB ROM & Gait Analysis \\
\hline Grade 1 & $\begin{array}{l}\text { No pain or } \\
\text { laxity }\end{array}$ & $.5 \mathrm{~cm}$ or less & $\begin{array}{l}\text { Little to no } \\
\text { pain over } \\
\text { ATF }\end{array}$ & $\begin{array}{ll}\text { Little } & \text { to } \\
\text { tolerable } & \\
\text { pain } & \end{array}$ & $\begin{array}{l}\text { Within } 7^{\circ} \text { of } \\
\text { contralateral } \\
\text { movements }\end{array}$ & $\begin{array}{l}\text { Normal with } \\
\text { little to no pain }\end{array}$ \\
\hline Grade 2 & $\begin{array}{l}\text { Laxity present } \\
\text { with/without } \\
\text { pain }\end{array}$ & $\begin{array}{l}\text { Between } \\
\text { and } 2.0 \mathrm{~cm}\end{array}$ & $\begin{array}{l}\text { Little to } \\
\text { moderate } \\
\text { pain over } \\
\text { ATF }\end{array}$ & $\begin{array}{l}\text { Moderate } \\
\text { pain }\end{array}$ & $\begin{array}{l}\text { Greater than } 7^{\circ} \\
\text { difference of } \\
\text { contralateral } \\
\text { movements }\end{array}$ & $\begin{array}{lr}\text { Antalgic } & \text { gait } \\
\text { present } & \text { with } \\
\text { pain } & \end{array}$ \\
\hline Grade 3 & $\begin{array}{l}\text { Laxity with no } \\
\text { end point }\end{array}$ & $\geq 2.0 \mathrm{~cm}$ & $\begin{array}{l}\text { Extreme } \\
\text { pain over } \\
\text { ATF }\end{array}$ & $\begin{array}{l}\text { Extreme pain } \\
\text { to unable to } \\
\text { perform }\end{array}$ & $\begin{array}{l}\text { Greater than } \\
10^{\circ} \text { difference } \\
\text { of contralateral } \\
\text { movements }\end{array}$ & $\begin{array}{l}\text { Unable } \\
\text { perform }\end{array}$ \\
\hline
\end{tabular}

Table 2. Lateral Ankle Sprain Classification 1,4,31-33

SLS=Single Leg Stance; NWB ROM=Non-weight bearing range of motion

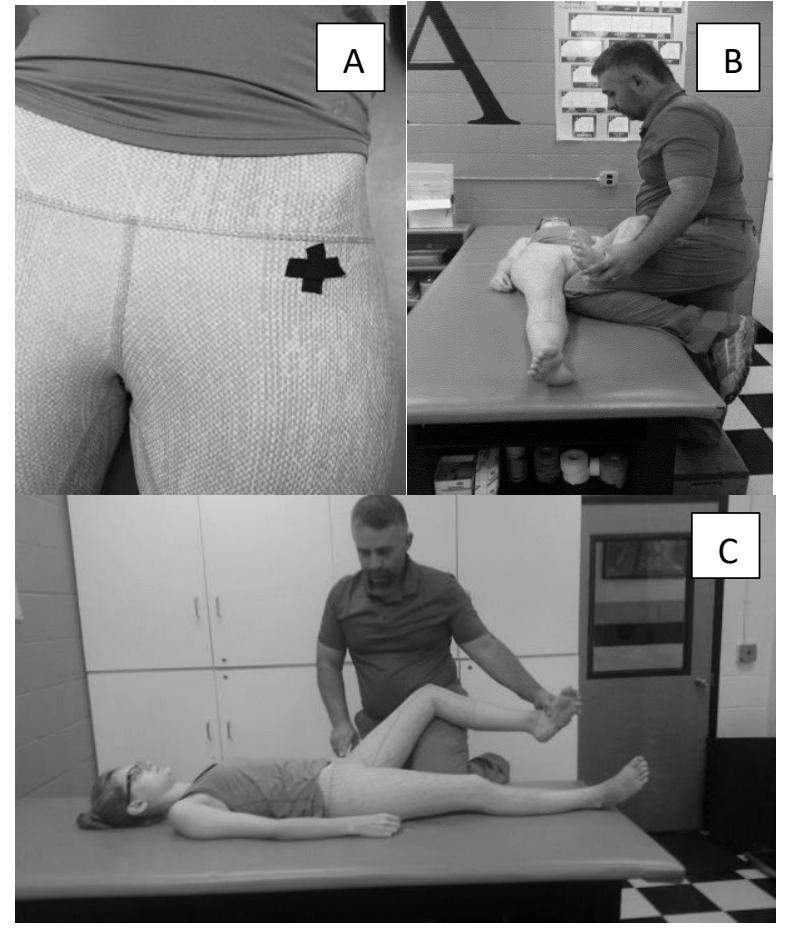

Figure 1

Examples A-C picture the RI TrP and PRT technique utilized for the apparent lateral ankle sprain. (A) $\operatorname{Tr} P$ along the ipsilateral Sartorius origin indicated by the " $X$ ". (B) Caudal view of the PRT Sartorius release technique. (C) Side view of the PRT Sartorius release technique.

The Disablement in the Physically Active scale (DPA) is a patient related outcome designed to assess a patient's perception of their injury and how it effects the quality of life and/or physical activity. The DPA is completed by the patient and ranges in scores from 0 to 64, with a lower score indicating less impact on daily life functions. ${ }^{28}$ The MCID values related to DPA have been calculated at nine points, for acute injuries, and six points, for chronic injuries. ${ }^{29}$ The utilization of the Patient-
Specific Functional Scale (PFSF) was added to assess the patient's perceived functional ability in performing more active or sports related movements deemed meaningful to the patient. Each movement/activity is scored from 0 ("unable to perform") to 10 ("able to perform the activity/movement at the same level before injury"). ${ }^{30}$ Scores for PFSF can be analyzed individually or as an average score of all activities/movements. ${ }^{30}$ The MCID for PFSF is 2 points for analyzing an average score or 3 points for an individual movement/activity. ${ }^{30}$

The foot and ankle ability measure (FAAM) is a reliable patient related outcome (PRO) measure for evaluating a wide range of physical dysfunctions and disorders involving the lower leg, foot, and ankle. The FAAM is broken down into two different questionnaires. One consists of 21 items that are associated with active daily living (ADL) and the other is an 8 item sub section specifically focusing on sports related movements. ${ }^{31}$ Each item gives the patient the ability to rate the associated movement/activity on a scale from "no difficulty" (4 points) to "unable to do/perform" (0 points). ${ }^{31}$ At the end of each section all of the points are added up, divided by the total possible score (84 points for ADL and 32 points for sports), and then multiplied by a 100 to give a final "score". ${ }^{31}$ The MCID for both the FAAM ADL and FAAM sport have 
been calculated to be 8 and 9 points respectively. ${ }^{31}$

The PRO NRS (TP, SLS, \& running) and goniometer measurements were collected prior to treatment, immediately following each treatment, 24 hours post treatment, one week post initial treatment, two weeks post initial treatment, and one month post initial treatment. Additional PRO of FAAM ADL, FAAM sport, PSFS, and DPA were collected prior to treatment, 24 hours post initial treatment, one week post initial treatment, two weeks post initial treatment, and one month post initial treatment.

\section{INTERVENTION}

After no PILL effect was found with MC fibular glide, the patients complained of lacking the ability to perform full DF, and had ipsilateral hip pain while attempting TB DF exercises; the primary researcher performed PRT to the ipsilateral Sartorius origin one time (Figure 1B \& 1C). Subsequently after the PRT Sartorius treatment, patients showed improved DF measurements and a PILL effect was obtained for the MC fibular glide. The MC fibular glide was then performed for three sets of ten repetitions. As the patient's chief complaints were alleviated within each treatment of PRT and MC, further assessment was performed to establish the patients' functionality (non-weight bearing, weight bearing, walking, jogging, running) (Table 1). At the end of treatment, a MC fibular glide taping was applied with Omnifix and Leukotape remain in place until the next day.

\section{RESULTS}

Significant intra-session improvements were observed within NRS and ROM measures. Both patients received two treatments 24 hours apart and were returned pain-free immediately back to practice after the conclusion of the second treatment session. Any associated laxity while performing anterior drawer test was absent after treatment. The improvements were sustained at one week, two weeks, and one month after being discharged following the second treatment. Moreover, both patients showed a significant improvement in DF following the application of PRT to the Sartorius origin that was sustained (Table 1). After each patient was treated with PRT, they regained $17^{\circ}$ and $11^{\circ}$ respectively, which was sustained until discharge and during follow-ups.

\section{DISCUSION}

According to current clinical criteria used for the classification of lateral ankle sprains includes the use of the anterior drawer test, pain to palpate over ATFL, weight bearing/SLS, differences in ROM measurements, and gait analysis (Table 2). 1,4,31-33 The two patients in this case report presented with criteria consistent with a grade two LAS and was the working diagnosis for the primary researcher. Additionally, no PILL effect could be found while performing MC MWM on either patient and both patients complained of varying pain along the ipsilateral anteriolateral hip while attempting to perform resisted DF exercise. Intrinsically, a greater importance was placed upon restoring normal tensegrity and arthrokinematic aspects associated with their primary complaints related to LAS which were monitored throughout the rehabilitation process using PRO and goniometric measurements.

Currently there are no studies examining the immediate effects of PRO with acute LAS while utilizing a RI approach (i.e., treating remotely). Furthermore, there are no current RI or pathoanatomical models supporting the RI correlation between ipsilateral sartorius TP and LAS pain. Nevertheless, in this exploratory case report, patients diagnosed with a grade two LAS reported improvements in pain immediately after treatment and at subsequent follow-ups after a RI PRT intervention at the ipsilateral Sartorius was performed which allowed the clinician to obtain a PILL effect for MC fibular glides. While these preliminary findings are unique, there are previous RI studies linking ankle and foot pathologies to other injuries or painful conditions. Navicular arthrokinematic 
dysfunction, limited DF ROM, and excessive ankle pronation have been linked to low back pain, sacroiliac dysfunction, and other lumbopelvic pathlologies. ${ }^{34-36}$ Conversely; postural stabilization, hip torque, decreased hip activation while walking or jumping, and ipsilateral hip abductor weakness have been connected to or are affected by LAS. ${ }^{16,} 37-42$ While direct comparisons cannot be made due to the significant differences between studies, it lends some support to include a RI assessment technique for the evaluation and treatment of LAS.

In this case report, a significant level of importance was placed upon resolving the patients' chief complaints from both local and global stand points. While MC has been found to be a very reliable and effective method of manual therapy for LAS, no PILL effect could be obtained during the evaluation and/or initial treatment of either patient in this case study. ${ }^{43-46}$ According to the MC methodologies, MWM would not be warranted in these patient's cases. ${ }^{26}$ However; in the current case study, not only was a PILL effect obtained after a RI-based treatment was performed, but also an immediate DF increase was observed in both cases. The treatment of both patients innately resolved their primary complaints related to their LAS and returned them to their sports expeditiously.

Limitations of the current study include the lack of control group or a comparison group. In addition to the lack of comparison group or randomized controls, each patient was allowed to participate in sports related activities as tolerated by the patients' in season sport. The primary researcher only treated one TP located at the ipsilateral sartorius origin and did not scan or treat any other TP which could have been present.

\section{CONCLUSION}

In this novel case study, this is the first report to present outcomes on the use of a RI based intervention of PRT to the ipsilateral sartorius origin for increasing ankle DF and aiding in obtaining a PILL response in patients with a primary complaint of LAS. Patients were able to return to full activity with no pain that was sustained for at least one month after treatment. In these two cases the clinician was able to effectively use an RI approach to treat grade two LAS, however, further research is required to verify these findings. While RI concepts are still being researched and explored "clinicians should continue to identify a specific pathoanatomic source of the patient's symptoms"; however, "they should also consider impairments of other systems/regions that directly or indirectly associate with the patient's complaint". ${ }^{17}$

\section{REFERENCES}

1. Kaminski TW, Hertel J, Amendola N, Docherty C, Dolan M, Hopkins J, Nussbaum E, Poppy W, Richie D.National Athletic Trainers' Association position statement: conservative management and prevention of ankle sprains in athletes. J Athl Train. 2013; 48(4):528-45. https://doi.org/10.4085/1062-6050-48.4.02

2. Adams J, Barton E, Collings J, DeBelieux P, Gisondi M, Nadel E. Emergency Medicine. Philadelphia, PA:

Elsevier, Inc.; 2008.

3. Kemler E, van de Port I, Backx F, van Dijk CN. A systematic review on the treatment of acute ankle sprain: brace versus other functional treatment types. Sports Med. 2011; 41(3):185-97.

https://doi.org/10.2165/11584370-000000000$\underline{00000}$

4. Kerkhoffs GM, van den Bekerom M, Elders L. Diagnosis, treatment and prevention of ankle sprains: an evidence-based clinical guideline. Br J Sports Med. 2012; 46(12):854-60.

https://doi.org/10.1136/bjsports-2011-090490

5. Lin C-WC, Uegaki K, Coupé VMH, Kerkhoffs GM, van Tulder MW. Economic evaluations of diagnostic tests, treatment and prevention for lateral ankle sprains: a systematic review. Br J Sports Med. 2013; 47(18):1144-9. https://doi.org/10.1136/bjsports2012-090319

6. Terada M, Pietrosimone BG, Gribble P. Therapeutic interventions for increasing ankle dorsiflexion after ankle sprain: a systematic review. J Athl Train. 2013; 48(5):696-709. https://doi.org/10.4085/1062-6050$\underline{48.4 .11}$

7. Safran MR, Zachazewski J, Benedetti R, Bartolozzi A, Mandelbaum R. Lateral ankle sprains: a comprehensive review Part 2: treatment and rehabilitation with an emphasis on the athlete. Med Sci Sports Exerc. 1999; 31(7 supplement):438-47. https://doi.org/10.1016/S0161-4754(00)90136-2

8. Fong C-M, Blackburn JT, Norcross MF, McGrath M, Padua D. Ankle-dorsiflexion range of motion and 
landing biomechanics. J Athl Train. 2011; 46(1):5-10. https://doi.org/10.4085/1062-6050-46.1.5

9. Hopper, D., Samsson, K., Hulenik, T., Ng, C., Hall, T., \& Robinson, K.. The influence of Mulligan ankle taping during balance performance in subjects with unilateral chronic ankle instability. Physical Therapy In Sport: Official Journal of The Association Of Chartered Physiotherapists In Sports Medicine. 2009; 10(4), 125130. https://doi.org/10.1016/i.ptsp.2009.07.005

10. Mau, H., \& Baker, R. T. A modified mobilization-withmovement to treat a lateral ankle sprain. International Journal Of Sports Physical Therapy. 2014; 9(4), 540548.

11. Cruz-Díaz, D., Lomas Vega, R., Osuna-Pérez, M. C., HitaContreras, F., Martínez-Amat, A. Effects of joint mobilization on chronic ankle instability: a randomized controlled trial. Disability And Rehabilitation. 2014; 1-10. https://doi.org/10.3109/09638288.2014.935877

12. Collins, C. K., Masaracchio, M., \& Cleland, J. A. The effectiveness of strain counterstrain in the treatment of patients with chronic ankle instability: A randomized clinical trial. The Journal of Manual \& Manipulative Therapy. 2014; 22(3), 119-128. https://doi.org/10.1179/2042618614Y.0000000069

13. Tateuchi H, Tsukagoshi R, Fukumoto Y, Oda S, Ichihashi N. Immediate effects of different ankle pushoff instructions during walking exercise on hip kinematics and kinetics in individuals with total hip arthroplasty. Gait Posture. 2011; 33(4):609-14. https://doi.org/10.1016/i.gaitpost.2011.01.018

14. Brown CN, Padua D, Marshall SW, Guskiewicz KM. Hip kinematics during a stop-jump task in patients with chronic ankle instability. J Athl Train. 2011; 46(5):4617. https://doi.org/10.4085/1062-6050-46.5.461

15. Tabrizi P, McIntyre WM, Quesnel MB, Howard W. Limited dorsiflexion predisposes to injuries of the ankle in children. J Bone Joint Surg Br. 2000; 82(8):1103-6. https://doi.org/10.1302/0301620X.82B8.10134

16. Gribble P, Robinson R. An examination of ankle, knee, and hip torque production in individuals with chronic ankle instability. Journal of Strength and Conditioning Research/National Strength \& Conditioning Association. 2009. 23(2): 395-400. https://doi.org/10.1519/ISC.0b013e31818efbb2

17. Sueki D, Cleland J, Wainner R. A regional interdependence model of musculoskeletal dysfunction: research, mechanisms, and clinical implications. J Man Manip Ther. 2013; 21(2):90-102. https://doi.org/10.1179/2042618612Y.0000000027

18. Wainner K, Whitman J, Cleland J, Flynn T. Regional interdependence: a musculoskeletal examination model whose time has come. J Orthop Sports Phys Ther. 2007; (11), 658-660. https://doi.org/10.2519/jospt.2007.0110

19. D’Ambrogio KJ, Roth GB. Positional Release Therapy. Mosby; 1997.
20. Speicher T. Clinical Guide to Positional Release Therapy. Human Kinetics; 2016.

21. Baker R, Nasypany A, Seegmiller J, Baker J, Nessler T. Treatment of Acute Torticollis Using Positional Release Therapy: Part 1. J of Athl Ther \& Train. 2013; 18(2): 34-37. https://doi.org/10.1123/ijatt.18.2.34

22. Baker R, Nasypany A, Seegmiller J, Baker J. Treatment of Acute Torticollis using Postional Release Therapy: Part 2. J of Athl Ther \& Train. 2013; 18(2):38-43. https://doi.org/10.1123/ijatt.18.2.38

23. Rhinehart A, Buonopane M. Use of the Mulligan Concept and Positional Release Therapy in the Treatment of a Moderate Grade Acromioclavicular Injury: A Case Review. Athletic Training \& Sports Health Care. 2016. 8(2): 82-88. https://doi.org/10.3928/19425864-20160203-01

24. Ghanbari A, Rahimijaberi A, Mohamadi M, Abbasi L, Sarvestani FK. The effect of trigger point management by positional release therapy on tension type headache. NeuroRehabilitation. 2012;30(4):333-339. https://doi.org/10.3233/NRE-2012-0764

25. Mohamadi M, Ghanbari A, Rahimi Jaberi A. Tension Type - Headache treated by Positional Release Therapy: a case report. Man Ther. 2012;17(5):456458. https://doi.org/10.1016/j.math.2012.04.005

26. Mulligan B. Mulligan Concept: Manual Therapy NAGS, SNAGS, MWM etc. $6^{\text {th }}$ Ed. Plane View Services Ltd; 2010

27. Salaffi F, Stancati A, Silvertri A, Ciapetti A, Grassi W. Minimal clinically important changes in chronic musculoskeletal pain intensity measured on a numerical rating scale. Euro J of Pain. 2004; 8(4):283291. https://doi.org/10.1016/j.ejpain.2003.09.004

28. Vela LI, Denegar CR. Transient disablement in the physically active with musculoskeletal injuries, part I: a descriptive model. Journal of Athletic Training. 2010;45(6):615-629. https://doi.org/10.4085/1062$\underline{6050-45.6 .615}$

29. Vela LI, Denegar CR. The Disablement in the Physically Active Scale, part II: the psychometric properties of an outcomes scale for musculoskeletal injuries. Journal of Athletic Training. 2010;45(6):630- 641. https://doi.org/10.4085/1062-6050-45.6.630

30. Young IA, Cleland JA, Michener LA, Brown C. Reliability, construct validity, and responsiveness of the neck disability index, patient-specific functional scale, and numeric pain rating scale in patients with cervical radiculopathy. American journal of physical medicine \& rehabilitation / Association of Academic Physiatrists. 2010;89(10):831-839. https://doi.org/10.1097/PHM.0b013e3181ec98e6

31. Martin R, Davenport T, Paulseth S, Wukich D, Godges J. Ankle Stability and Movement Coordination Impairments: Ankle Ligament Sprains. J Orthop Sports Phys Ther. 2013. 43(9): A1-A40. https://doi.org/10.2519/jospt.2013.0305

32. Hiller CE, Nightingale EJ, Lin C-WC, Coughlan GF, Caulfield B, Delahunt E. Characteristics of people with recurrent ankle sprains: a systematic review with 
meta-analysis. Br J Sports Med. 2011; 45(8):660-72. https://doi.org/10.1136/bjsm.2010.077404

33. Stanley K. Ankle sprains are always more than "just a sprain." Postgrad Med. 1991; 89(1):251-255. https://doi.org/10.1080/00325481.1991.11700802

34. Cibulka M. Low back pain and its relation to the hip and foot. J Orthop Sports Phys Ther. 1999; 29(10):595601. https://doi.org/10.2519/jospt.1999.29.10.595

35. Rothbart B, Estabrook L. Excessive pronation: a major biomechanical determinant in the development of chondromalacia and pelvic lists. J Manipulative Physiol Ther. 1988; 11(5): 373-9.

36. Brantingham J, Lee Gilbert J, Shaik J, Globe G. Sagittal plane blockage of the foot, ankle, and hallux and foot alignment-prevalence and association with low back pain. J Chiropr Med. 2006; 5(4):123-7. https://doi.org/10.1016/S0899-3467(07)60144-X

37. Lewis CL, Ferris DP. Walking with increased ankle pushoff decreases hip muscle moments. J Biomech. 2008; 41(10):2082-9. https://doi.org/10.1016/i.jbiomech.2008.05.013

38. Frigon A, Sirois J, Gossard J-P. Effects of ankle and hip muscle afferent inputs on rhythm generation during fictive locomotion. J Neurophysiol. 2010; 103(3):1591605. https://doi.org/10.1152/jn.01028.2009

39. Cobb SC, Bazett-Jones DM, Joshi MN, Earl-Boehm JE, James CR. The relationship among foot posture, core and lower extremity muscle function, and postural stability. J Athl Train. 2014; 49(2):173-80. https://doi.org/10.4085/1062-6050-49.2.0

40. Chon S-C, You JH, Saliba S. Cocontraction of ankle dorsiflexors and transversus abdominis function in patients with low back pain. J Athl Train. 2012; 47(4):379-89 https://doi.org/10.4085/1062-6050$\underline{47.4 .12}$

41. Bullock-Saxton J. Local sensation changes and altered hip muscle function following severe ankle sprain. Physical Therapy. 1994. 74(1): 17-28. https://doi.org/10.1093/ptj/74.1.17

42. Friel K, McLean N, Myers C, \& Caceres M. Ipsilateral hip abductor weakness after inversion ankle sprain. JAT. 2006. 41(1): 74-78.

43. Pellow J, Brantingham J. The efficacy of adjusting the ankle in the treatment of acute and chronic grade I and grade II ankle inversion sprains. J Manipulative Physiol Ther. 2001; 24:17-24. https://doi.org/10.1067/mmt.2001.112015

44. Collins N, Teys P, Vicenzino B. The initial effects of a Mulligan's mobilization with movement technique on dorsiflexion and pain in subacute ankle sprains. Man Ther. 2004; 9: 77-82. https://doi.org/10.1016/S1356689X(03)00101-2

45. O'Brien T, Vicenzino B. A study of the effects of Mulligan's mobilizations with movement treatment of lateral ankle pain using a case study design. Man Ther. 1998; 3(2):78-84. https://doi.org/10.1016/S1356689X(98)80022-2

46. Whitman JM, Childs JD, Walker V. The use of manipulation in a patient with an ankle sprain injury not responding to conventional management: a case report. Man Ther. 2005;10(3):224-231. https://doi.org/10.1016/j.math.2004.10.003 